\title{
Towards a climate change justice theory?
}

\author{
Upendra Baxi \\ Professor of Law in Development, Warwick and Delhi
}

Approaches to justice are an infrequent phenomenon in the analysis of global change policies pursued by states and international organizations but are writ large in global civil society protests and advocacy. I hope to initiate, through this paper, a different conversation concerning theories of climate justice (TCJ) in the offing and ask questions about how different TCJs may be from theories about global justice (TGJ) and environmental justice (TEJ). These approaches are all related of course - but the questions that interest me pertain to the distinctions and differences between them. Although TEJs remain tethered to domestic and regional social orderings, they generally come closer to TCJs than TGJS do. I argue here that another important difference between TEJS and TCJS concerns the notion of 'generations' in TCJs. This goes beyond the three generations (past, present and future) in most accounts of TGJ to encompass infinite generations. In addition, I examine the notion that there is a human right to do harm and the ways in which TCJ may address harm prevention as the cornerstone of a new planetary approach to justice.

Keywords: climate justice theory, theories about global justice, environmental justice, anthropocene, generations, harm principle, infinite generations, infinite justice

I need a watchman to tell me this is what a man says but this what he means, to draw a line down the middle and say here is this justice and there is that justice and make me understand the difference. I need a watchman to go forth and proclaim to them all that twenty-six years is too long to play the joke on anybody, no matter how funny it is. ${ }^{1}$

\section{PROLOGUE}

How does one draw a 'line' between this justice and that justice? And how does one besides a prayer, whether religious or secular - gather the courage to think of justice beyond and outside the law from justice before and according to the law? No doubt the justice problems of the Anthropocene - regarded by some as a cruel joke played by Nature but by others, more rightly, as a contribution of 'corporate legal humanity' (as Anna Grear calls it) ${ }^{2}$ over at least three centuries - are a mix of some ancient and some very new concerns. A general aim of all theories of justice is of course - and has always been - to perform the role of a watchman. However, we require a 'watchman' also to tell us the 'difference' between 'this' or 'that' (or our and their) justice and to enable a choice between them. And quis custodiet ipsos custodes? What if no 'watchman' can found? These difficulties do not abate with climate change justice and indeed are rendered more poignant by it.

1. Harper Lee, Go Set a Watchman (William Heinemann, London 2015) at 181-2.

2. A Grear, Redirecting Human Rights: Facing the Challenge of Corporate Legal Humanity (Palgrave Macmillan, London 2010). 
To start with, I apologize for adding three more acronyms to the heavily acronymridden contemporary world - TCJ, TGJ, TEJ (theories of, and about, respectively, climate change justice, global justice and environmental justice). My otherwise environmentally friendly justification is that these are all theories about the 'justness' ${ }^{3}$ of global change policies, especially important because dreaded even in UN global human rights and social policy discourse. ${ }^{4}$ In contrast, the wretched of the earth (and social movements representing these ${ }^{5}$ - from the Prague Spring to the Arab Spring $^{6}$ and beyond to the 'Occupy Now' and $99 \%$ movements) ${ }^{7}$ think of justice beyond the law even as they help us to re-think justice according to the law. In speaking about climate change justice, we necessarily rethink and repoliticize (even polarize) the previously depoliticized, cover large fields of aggregate data on governance, social movements and resistance, vast territories of thought, some intractable conceptual concerns, and different (and some only now emerging) competing narratives. Such rethinking and repoliticization are the twin overriding imperatives of new global social change and justice theory such that these, and associated, narrative risks need to be run.

Like many of us, I have thought about justice according to the law and justice beyond the law all my life. In particular, I have thought about a theory of justice for domestic societies ever since John Rawls wrote his three principles of justice, which he subsequently modified in some detail and also developed as a matter of principle

3. AA Ehrenzweig, Psychoanalytic Jurisprudence (Oceana Publications, Dobbs Ferry, NY 1971).

4. I have worried about the dread, and absence, of the ' $\mathrm{J}$ ' (justice) word from the discourse of global public policy and the law and tried to imagine what the world will look life if 'justice' as struggle were recognized as a civic virtue, instead of being treated as an insurrection which must anyhow be repressed or suppressed in the name of collective global, regional or domestic interests of security. I have realized that while a shift to 'justice' and away from the 'law' was important, it raised all sorts of impossible problems, not that indwelling the law of the dominant is any the less problematic. See U Baxi, 'The Place of the Human Right to Health and Contemporary Approaches to Global Justice: Some Impertinent Interrogations' in J Harrington and M Stuttaford (eds), Global Health and Human Rights (Routledge, Abingdon 2010) 12-27.

5. See M Kaldor, Global Civil Society: An Answer to War (Polity Press, Cambridge 2003); U Baxi, Future of Human Rights (Oxford University Press, Perennial Edition, Delhi 2013). This work shall be cited hereafter as 'Baxi, Future').

6. The present generation, save the historians, have almost forgotten the history of the 'Prague Spring'! But see G Golan, The Czechoslovak Reform Movement (Cambridge University Press, Cambridge 1973); VV Kusin, The Intellectual Origins of the Prague Spring. The Development of Reformist Ideas in Czechoslovakia 1956-1967 (Cambridge University Press, Cambridge 1971). For a brief history of the Arab Spring, see V Prashad, Arab Spring, Libyan Winter (LeftWord Books, Delhi 2012), A Stephan and JL Linz, 'Democratization Theory and Arab Spring' (2013) 24(2) Journal of Democracy 15-30; A Zwitter, 'The Arab Uprising: State of Emergency and Constitutional Reform', University of Groningen Faculty of Law Research Paper Series (2013); M Kamrava (ed) Beyond the Arab Spring: The Evolving Ruling Bargain in the Middle East (Oxford University Press, Oxford 2014); see also P Mindus, 'Sorting out Modern Constitutional Emergencies: A Taxonomic Approach' <http://redescriptions.fi/media/ uploads/mindus.pdf> accessed 1 June 2014.

7. B de Souza Santos, 'Occupy the Law: Can Law be Emancipatory?', lecture given at University of Birkbeck, London <http://alice.ces.uc.pt/en/index.php/transformative-constitutionalism/ boaventura-de-sousa-santos-occupy-the-law-can-law-be-emancipatory/\#sthash.mA5r543K. dpuf/>. 
and as an approach to the theory of global justice. ${ }^{8}$ Of late, I have been anxious about theories of global justice raised implicitly by all this talk and action concerning 'environmental' or more accurately 'sustainable development' justice', ${ }^{9}$ considered generally as an aspect of global justice but here considered as different from aspects of TGJ and TCJ.

In my activist life, I have struggled to claim the human rights of the suffering peoples: to claim human rights that they have but do not exercise and human rights they '[do] not have' ${ }^{10}$ but seek to invoke. Or - more aptly - they exercise their 'right to have rights'. ${ }^{11}$ Their condition of human rightlessness often consists in what is called their 'abject submission'. What is important is not so much their subjectification - which is the ordinary or daily operation of sovereign power practices and tactics - but the struggle for de-subjectification or against sovereign impunity. For example, in the contexts of geographies of injustice constituted by mass disasters and toxic torts, the valiant violated struggle against claims of immunity and impunity by mighty multinationals. The problem of justice (and human rights) has always perplexed me: at one end of their struggle the perspectives of the masses of the impoverished, socially vulnerable and disposable peoples in the modern neoliberal world seek justice that is impossible now $;{ }^{12}$ at the other, they enact their struggles as if justice was realizable here and now and even in the circumstance of their own choosing.

8. There are in fact three - all interrelated - Rawls: A Theory of Justice (Harvard University Press, Cambridge, MA 1971); Political Liberalism (Columbia University Press, New York 1973) and Law of Peoples (Harvard University Press, Cambridge, MA 1999). The moves from a deontological theory of justice to justice as 'political' and from there on to a law of peoples are highly significant. Serious students of Rawls' thought have seen that its basic structure is continuous on the whole, but have also seen that its essential features have changed over the decades. I use the stunningly original language from a great, even if deeply conflicted, doctrine of "basic structure' and 'essential features' from the Indian Supreme Court decision in Kesavananda Bharathi v State of Kerala [1973] 4 SCC 225 ('Kesavananda'). See, for references to literature and a critique, U Baxi, 'Global Justice and the Failure of Deliberative Democracy' in O Enwezor et al. (eds), Democracy Unrealized: DOCUMENTA 11, PLATFORM 1 (Hatje Cantz Publishers, Ostfildren-Ruis, Germany 2002).

9. See G Walker, Environmental Justice: Concepts, Evidence and Politics (Routledge, London 2012; hereafter cited by the author) and R Holifield, M Potter and G Walker (eds), Spaces of Environmental Justice (Wiley-Blackwell, Chichester, West Sussex 2010); and, in a different vein, A Philippopoulos (ed), Law and Ecology: New Environmental Foundations (Taylor \& Francis, London 2011).

10. J Rancière, 'Who is the Subject of the Rights of Man?' (2004) 103(2-3) South Atlantic Quarterly 297-310; The Philosopher and his Poor (Duke University Press, Durham, NC 2003). Rancière demonstrates ways in which human rights discourse may be immunized from the Siamese twins of imperialism and colonialism, in suggesting the radical emancipatory political. 11. H Arendt, The Origins of Totalitarianism (Harcourt Books, New York, 1994) 278-9, 292, 299-300; P Birmingham, Hannah Arendt and Human Rights: The Predicament of Common Responsibility (Indiana University Press, Bloomington 2006). See also A Kesby, The Right to Have Rights: Citizenship, Humanity, and International Law (Oxford University Press, Oxford 2012). 12. I think, and rethink, the Bhopal Catastrophe but examples of mass disasters, toxic torts and industry-sponsored toxic capitalism abound. See as to Bhopal, U Baxi, 'Human Rights Responsibility of Multinational Corporations, Political Ecology of Injustice: Learning from Bhopal Thirty Plus?' (2016) 1(1) Journal of Business and Human Rights 21-40; 'Writing about Impunity and Environment: The "Silver Jubilee" of the Bhopal Catastrophe' (2010) 1 Journal of Human Rights and the Environment 23; 'The "Just War" for Profit and Power: The Bhopal Catastrophe and the Principle of Double Effect' in L Bomann-Larsen and 
More conventionally put, there is the question of whether we need at all a theory of justice or whether global social change policies will do. The question of urgency of global social policy is often considered vast enough to permit the luxury of ethical deliberation; yet, it is also cogently urged that such polices make little progress until they represent the basic socio-ethical convictions that underlie theories of justice. Often enough, unexamined assumptions rule global social change policies, foregrounding the task of moral philosophers to unveil and examine these fully. While the complex questions concerning the relationship between public policy and philosophy cannot be explored here, I consider as self-evident that ethical exploration of the aporia, or paradox, of justice ought to accompany the making and implementation of global climate justice. ${ }^{13}$

O Wiggen (eds), Responsibility in World Business: Managing Harmful Side-effects of Corporate Activity (United Nations University Press, Tokyo 2004) 175; 'The Geographies of Injustice: Human Rights at the Altar of Convenience' in C Scott (ed), Torture as Tort: Comparative Perspectives on the Development of Transnational Human Rights Litigation (Hart, London 2001) 197. It is a measure of time and discipline that the admirable work of K Fortun, Environmentalism, Disaster, New Global Orders (University of Chicago Press, 2001) takes little notice of my scholarly and activist work on Bhopal; Kim Fortun gives a fascinating narrative of 'advocacy' in and after Bhopal, and her elucidations of the notion of 'enunciatory communities' is extremely important in exploring mass disasters. I have recently discussed her work, along with the work of early Veena Das in my seminar talk at the Department of Sociology, Delhi University, entitled: 'The Bhopal Catastrophe Narratives: Where Law and Anthropology Meet, but Not Quite?' (4 September 2015).

13. See, for the diverse considerations that lead to this result, D Moellendorf (ed), The Moral Challenge of Dangerous Climate Change: Values, Poverty, and Policy (Cambridge University Press, Cambridge 2014); M Risse, 'A Précis of On Global Justice, with Emphasis on Implications for International Institutions' (2015) 56(6) Boston College Law Review 1037-61; MC Nussbaum, 'Climate Change: Why Theories of Justice Matter' (2013) 13 Chicago Journal of International Law 469. Nussbaum shows how 'a suitably flexible and realistic normative theory is actually very valuable, as a road map that will help us move toward our destination' (486) but also states that 'some important conceptual matters will have to be settled at, or near, the outset' (485). See, on a different register, 'Appendix C: The Right to Sustainable Development versus International Paretianism' in Moellendorf, loc.cit., at 236-9. Maxine Burkett, has focused on the notion of a 'justice paradox' devised and developed by RE Scott in 'Chaos Theory and the Justice Paradox' (1993) 35 Wm. \& Mary L. Rev. 329-51, which broadly consists in the fact that 'we aspire to a just society that satisfies the essential conditions of both Present and Future Justice, and yet we live in a world that often forces us to choose between one or the other' (at 330). Maxine Burkett has nuanced this distinction between present and future to represent a situation where a 'justice paradox' occurs because the 'current international legal regime forecloses any reasonable attempts at a just remedy for the victims of climate change who are the most vulnerable and the least responsible. Worse still, attempts to seek justice in such clear instances of need may yield negative political outcomes against the claimants themselves, namely the loss of aid for other critical functions from wealthy large emitters'; and yet the struggle against domination must be waged and continue. See Burkett's 'A Justice Paradox: On Climate Change, Small Island Developing States, and the Quest for Effective Legal Remedy' (2013) 35 U. Haw. L. Rev. 633 at 634; ead., 'A Justice Paradox: Climate Change, Small Island States and the Absence of International Legal Remedy', in S Alam, S Atapattu and CG Gonzalez (eds), International Environmental Law and the Global South (Cambridge University Press, Cambridge 2015) 435-50; and MB Gerrard and GE Wannier (eds), Threatened Island Nations: Legal Implications of Rising Seas and a Changing Climate (Cambridge University Press, Cambridge 2013). 
A question of great moment concerns the posited difference between theory and praxis - a sub-question I have wrestled with severally. ${ }^{14}$ Here, I put the matter in terms of a contrast between theories about justice and the experience of injustice. Edmond Cahn made a great contribution in naming the latter a 'sense of injustice'. ${ }^{15}$ Perhaps, not too much is lost in a translation that interprets 'sense' as 'expectations' of justice according to law and beyond the law. I put the contrast this way only partly because theories and practices of justice often shape our experience of injustice but are just as often independent of these. The problem of justice is the problem of compossibilty (being or happening together) as philosopher Gottfried Wilhelm Leibniz presented it - the problem of being together of the metaphysical and the natural worlds. The problem of best possible normative worlds is a problem of justice and also for law, ${ }^{16}$ and this is made more poignant by the climate change now happening and now upon us.

Sociologically, and socially, and regardless of what geologists may eventually do with the Anthropocene, the urgency of the struggle is clear, as Naomi Klein has recently stressed with her call; surely, we all must think anew, where political and ideological borders and boundaries make no sense on a planet in distress, where old loyalties need to be overthrown and replaced with a newly configured and urgent ethic of life for all. ${ }^{17}$ Perhaps we must rethink the question of responsibility and begin

14. U Baxi, Human Rights in a Posthuman World: Critical Essays (Oxford University Press, Delhi 2007).

15. EM Cahn, The Sense of Injustice (New York University Press, New York 1949). Cahn displayed a remarkable contempt for legal philosophy separated from life itself. He thus provocatively observed: 'Legal philosophy, when it has seen fit to turn its eyes toward men, has customarily regarded them either as a row of identical pegs on which to hang rights and interests or as mere particular instances of some conceptualized being called "Man"; ... but the ultimate consumer of the product will always be some quite concrete individual' (2). He thus fully anticipated the distinction that political theory was later to draw between the 'generalized' and 'concrete' other: see S Benhabib, Situating the Self (Routledge, New York 1992), see also J Sterba 'Benhabib and Rawls's Hypothetical Contractualism' (1994) 62 New German Critique 149-64.

For Cahn the sense of injustice consisted in the 'sympathetic reaction of outrage, horror, shock, resentment, and anger, those affections of the viscera and abnormal secretions of the adrenals that prepare the human animal to resist attack' (at 24). Whatever may be said about Cahn's barbs at the practice of doing legal theory, the 'sense of injustice' stands vividly described here, and in biopolitical terms too! See, also BS Ledewitz, 'Edmond Cahn's Sense of Injustice: A Contemporary Reintroduction' (1985) 3(2) Journal of Law and Religion 277-330.

16. See GW Leibniz, De Summa Rerum: Metaphysical Papers, 1675-1676. Trans. GHR Parkinson (Yale University Press, New Haven 1992); M Benson, 'Leibniz on Possible Worlds' in HG Frankfurt (ed), Leibniz: A Collection of Critical Essays (Doubleday, Garden City, NY 1972) 335-64; J Messina and D Rutherford, 'Leibniz on Compossibility' (2009) 4(6) Philosophy Compass 962-77. Leibniz (in translation) says, ' $[\mathrm{N}]$ ot all possibles are compossible. Thus, the universe is only a certain collection of compossibles, and the actual universe is the collection of all existing possibles, that is to say, those which form the richest composite. And since there are different combinations of possibilities, some of them better than others, there are many possible universes, each collection of compossibles making up one of them (Die Philosophische Schriften III 573/L 66Ed. C.I. Gerhardt. Berlin: Weidmann, 1875-90; reprint Hildesheim: Olms, 1960). It is out of so many possibles that we construct, and strive for, the best compossible normative worlds. See C Singh, From Anarchy to Utopia (Oxford University Press, Delhi 1984); U Baxi, 'Chattratpati Singh and the Idea of Legal Theory' (2014) 56(1) Journal of the Indian Law Institute 5-24.

17. N Klein, This Changes Everything: Capitalism versus Climate (Allen Lane/Penguin, London, 2014). This admirable work, designed to foster activist knowledge, legality, justice 
to think, with Jacques Derrida, not so much about responsibility which is at once undecidable and even unjustifiable, and instead to think about response-ability. One social meaning of the term 'response-ability' is 'openness to the suffering of the other', or, more precisely, towards 'the face of the other' (as Emmanuel Levinas used to say), ${ }^{18}$ a response-ability which must somehow become our 'political unconscious' (as Frederic Jameson phrased this), ${ }^{19}$ though philosophers here do not speak with one voice. In sum, the question of the political is as archaic as contemporary and future driven, and the question persists with greater force than ever before: How do we pursue climate change justice, confronted with both the injustice of capitalism and the problematique of life after capitalism?

How does one even begin to conduct conversation about justice in this epoch of climate change? Is there a distinctive body of thought and praxes that we may begin to label as TCJ? Is there a discourse about TCJ which is distinct from the theories about global justice and about environmental justice? If there is a distinction to be drawn, will it be a distinction of degree rather than of kind? I take the view that these three approaches to justice are discrete but interrelated, and that the relationship among them is not linear but multilinear and even multi-directional (as is shown by the earth's oldest First Nations peoples from whom all of us seek to learn now about the compossibility of the human and natural orderings) and that while we must utter the first few words and sentences, the later generations (if a prophesy is warranted) will more likely than not do more than lisp the alphabet of climate change justice.

Thus, the quest begins with many questions, which I have here stated summarily but do not address, except occasionally by indirection. Further issues also come to mind, raising questions locating the analysis to come - again, without necessarily silhouetting these here.

The first issue pertains to the idea of the human rights self (or collective selfhood) and its relation to justice theories. If we were fully to agree with the view that neoliberalism is constituted by a pervasive commodification of life and by what Michel Foucault recently called a conception self (and agency) as 'entrepreneurship', ${ }^{20}$

and solidarity among suffering and struggling peoples of the earth, is especially important in conveying a vivid description of the tactics pursued by neoliberal markets and governments, especially job blackmail, 'desperation' as a means to predation and 'total control'. See Chapters 12 and 13 for some wise activist and sage counsel. See her highly popular, and assiduously accurate, work The Shock Doctrine: The Rise of Disaster Capitalism (Metropolitan Books, New York 2007). In her 2014 work, Naomi Klein comes close to describing the uses of law as a 'tactic' foreshadowed by Michel Foucault: see A Hunt and G Wickham, Foucault and Law: Towards a Sociology of Law as Governance (Pluto Press, London 1994); A Beck, 'Foucault and Law: the Collapse of Law's Empire' (1996) 16(3) Oxford Journal of Legal Studies 489-502. See also V Tadros, 'Between Governance and Discipline: The Law and Michel Foucault' (1998) 18(1) Oxford Journal of Legal Studies 75-103. The distinctions among law, tactics, strategy and theory are quite crucial for TCJ.

18. See U Baxi, 'Judging Emmanuel Levinas? Some Reflections on Reading Levinas, Law, Politics' (2009) 72(1) Modern Law Review 116-29.

19. F Jameson, The Political Unconscious: Narrative as a Socially Symbolic Act (Methuen, London 1981).

20. L McNay, 'Self as Enterprise: Dilemmas of Control and Resistance in Foucault's The Birth of Biopolitics' (2009) 26(6) Theory, Culture \& Society 55-77. See also, J Donzelot, 'Michel Foucault and Liberal Intelligence' (2008) 37(1) Economy and Society 115-34. And see, of course, M Foucault, Society Must Be Defended. Lectures at the Collège de France 1975-1976 (Penguin, London 1997); Security, Territory, Population: Lectures at the Collège 
then perhaps all that remains of human beings is a self that is disposable (and is predisposed) to market and politics. Does TCJ engage the ontology and epistemology of a free market and neoliberal fragile self or does it address a rather robust human rights self with powers to resist the total domination of the economy and the polity? ${ }^{21}$ Is what now remains merely the conception of human beings entertained by active yet captive consumers and asocial capitalists (people as 'social capital')? What then is the place of rights and resistance in any approach to justice, and to climate change justice? Do human rights only constitute, as Foucault once said, a crucial 'episode' in a larger and longer struggle, which results in new 'cultural forms', ${ }^{22}$ or does the idea of human rights help us to overcome the deep structure of what Nietzsche once called 'passive nihilism', which can now best be described as political nihilism from above and below? ${ }^{23}$

The second issue concerns the kind of anticapitalistic and anti-'system' politics that should be pursued as a matter of response to the experience/expectations of injustice and to theories of climate justice. Is that politics merely 'sub-politics' (one that merely changes the players of the game) or 'meta-politics' (one that changes the rules of the game) $?^{24}$ Put another way, may one regard changing the players as important as changing the rules? But to change the rules equals changing the game itself, as rules are all that constitute the game in the first place. Are there different struggles about each of these modes of politics or do these coalesce/collapse into one or the other? If so, what aspect of that process is one of immediacy and what can be deferred to the future? Does heroic action lie in aspiring for structural transformation or does the tragic lie in accepting the episodic change gains?

The contrast between the episodic and the structural (the change of players versus the change of game) is quite crucial here. If the 'green' managers of governance are apt to convert climate change into episodic affairs, green activists seek to translate the episodic into structural matters. If climate change justice theorizing is to escape being rendered inconsequential altogether for the future, that justice has to happen here and now (in that 'now-time' as Walter Benjamin so acutely named it) as well as in the near future as we know it. Are human futures masked or unveiled in the events from the Czech Spring to the Arab Spring? And differently, what lessons may we learn from the 'Occupy Now' and '99\%' movements?

de France 1977-1978 (Palgrave Macmillan, Basingstoke 2008); and The Birth of Biopolitics: Lectures at the Collège de France: 1978-1979 (Palgrave Macmillan, Basingstoke 2008). See, on a different register, Freya Mathews, The Ecological Self (Routledge, London 1991); this insightful work seeks to fuse 'metaphysical archetypes' and 'systems theory' with the problem of locating 'value in nature and the meaning of life'.

21. A Supiot, The Spirit of Philadelphia: Social Justice vs. the Total Market (Verso, London 2012).

22. Michel Foucault, 'The Social Triumph of the Sexual Will', in P Rabinow (ed), Essential Works of Foucault 1954-84. Vol. 1: Ethics (Penguin, London 1994). Lois McNay, who quotes this, understands Foucault well when she observes: 'Rights discourse has a transient strategic utility, which might assist in the mitigation of injustice in a piecemeal way but is certainly far from being an effective or comprehensive approach to overcoming systemic oppression', McNay (n 20), at 72.

23. See M Heidegger, Nietzsche (University of Chicago Press, Chicago 1982) 55-6, 66.

24. U Beck, The Reinvention of Politics: Rethinking Modernity in the Global Social Order (Polity, Cambridge 1976); id., Ecological Politics in An Age of Risk (Cambridge, Polity Press 1995). But see, G Hanlon, 'Knowledge, Risk and Beck: Misconceptions of Expertise and Risk' (2010) 21(3) Critical Perspectives on Accounting 211-20.

25. See notes 6 and 7. 
The third issue relates to juridification. While this is one way to relate industrial mass disasters to the tasks of distributive global justice (and to measure them against it), ${ }^{26}$ climate change literature raises more pervasive and poignant questions. Abundant implications for justice arise out of the modes of working of international law, relations and organizations; out of how global distributive social policies in the making attend to the problems of climate change - the processes of depletion of the ozone layers and the production of greenhouse gases (GHG) - and out of direct attention to the role of state and non-state actors and agencies in causing the problem, and then in seeking to ameliorate it.

Against this prologue of multiplying questions, I now offer a more sustained reflection on, respectively, theories of global justice (TGJ), theories of environmental justice (TEJ) and theories of climate justice (TCJ), and on the conversation across the genres and the distinctions among them.

\section{THEORIES OF GLOBAL JUSTICE (TGJ)}

A first thing to note about TGJ is that these are of very recent origin ${ }^{27}$ and concern increasingly not so much international justice but global justice. International justice concerns principally state actors and conduct: peace among (and between) nations is considered to be the objective of inter-state justice. Among other justice values are legal regulation of armed conflicts, just bases for international cooperation, contemporary human rights norms and standards - particularly as enunciated and fostered by the UN and its specialized and other agencies - and global social change policies. TGJ expresses values of just relations between and among states and the (international/supranational and regional) organizations they create and sustain. These values are won often at the great costs of international conflicts, even wars, whether or not regarded as 'just' by those violated by them.

Historians of international law teach us that the foundations of modern international law were laid down in the Westphalian era (such as the doctrine of state sovereignty, the right of self-defence, freedom of the high seas or diplomatic immunity), ${ }^{28}$ that human rights discursivity is a distinctively twentieth-century phenomenon ${ }^{29}$ and that these lay down jus cognes, erga omnes, and core rights obligations peculiar to the post-Westphalian legal order. Unlike the previous order, the contemporary international law formation does not frown at some core human rights standards. Justice norms and standards are not strangers to international law - one especially thinks of the iusnaturalist thinkers in the West as well as East and of social action and resistance movements globally and locally. The first of many barriers has been, more

26. R Mathias and ME Ibarraran (eds), Distributional Impacts of Climate Change and Disasters (Edward Elgar, Cheltenham 2009). And see the qualitative analysis in many contributions in S Alam et al. (n 13).

27. In the second half of the twentieth century, the discourse really starts with John Rawls: see supra $\mathrm{n} 8$.

28. Though the organs of some of these principles may be traced back before the rise of Christianity, see U Baxi, 'India - Europe' in B Fassbender and A Peters with S Peter and D Högger (eds), The Oxford Handbook of the History of International Law (Oxford University Press, Oxford 2012) 744-64. See also, essays in Part 1 - 'History of North-South Divide and the Global Environmental Governance' in S Alam et al. (n 13) at 23-170.

29. Baxi, Future (n 5) Chapters 1 and 2. 
rather than less, crossed by some recent theorizing on global justice: there is agreement that we may speak of 'global justice', although the rights and obligations of the community of states thus stipulated remain a matter of contestation.

Global justice approaches/theories are infinitely various; these include utilitarian, cosmopolitan and deontological approaches, ${ }^{30}$ and the approach one takes depends on one's philosophical convictions. But it may be safely stated that TGJ do not confine themselves to justice within the borders and boundaries of domestic society but address the notions of justice across borders. Moreover, TGJ increasingly embrace (to use Rawlsian concepts) the contrast between the 'circumstances' and the 'tasks' of justice of states in interaction with non-state actors: in the main, international, regional and national civil society actors, business actors (mainly MNCs and other market players), scientists and other professionals, the print, electronic and social media (fomenting commenteriat, now almost replacing proletariat) and - most recently - armed insurgent groups across borders.

TGJ identify core or basic human rights as claims of justice. They are mostly concerned not with human rights law and jurisprudence or even with demosprudence ${ }^{31}$ but with the moral idea of human rights. Whether it be liberal or communitarian theory or even civic republican thought that serves as a platform for theory-construction, ${ }^{32}$ TGJ seem united in their determination to keep the number and nature of moral rights as human rights ${ }^{33}$ to as few as possible. Not every question, it is said, is a question of

30. See for a useful survey, C Johns, Global Justice: Defending Cosmopolitanism (Oxford University Press, Oxford 2001); see also, F Kurasawa, The Work of Global Justice: Human Rights as Practices (Cambridge University Press, Cambridge 2007); C Brown, 'Review Article: Theories of International Justice' (1997) 27 British Journal of Political Science 273-97; S Caney, 'Survey Article: Cosmopolitanism and the Law of Peoples' (2002) 10(1) Journal of Political Philosophy 95-123; FJ Garcia, 'Trade and Justice: Linking the Trade Linkage Debates' (1998) 19 University of Pennsylvania Journal of International Economic Law 391; R Forst, 'Towards a Critical Theory of Transnational Justice' (2001) 32(1-2) Metaphilosophy 160-77; C Barry and TW Pogge (eds), Global Institutions and Responsibilities: Achieving Global Justice (Wiley-Blackwell, Chichester, West Sussex 2006); P Van Parijs, 'International Distributive Justice' in RE Goodin, P Pettit and T Pogge (eds), A Companion to Contemporary Political Philosophy (Blackwell, Oxford 2007) Vol. 2, 638-52; D Miller, 'Justice and Global Inequality' in A Hurrell and N Woods (eds), Inequality, Globalization, and World Politics (Oxford University Press, Oxford 1999) 187-210; D Miller, Principles of Social Justice (Harvard University Press, Cambridge, MA 2001); T Nagel, 'The Problem of Global Justice' (2005) 33(2) Philosophy and Public Affairs 113-47; MC Nussbaum, Frontiers of Justice: Disability, Nationality, Species Membership (Harvard University Press, Cambridge, MA 2007). 31. U Baxi, 'Demosprudence v. Jurisprudence: The Indian Judicial Experience in the Context of Comparative Constitutional Studies' (2014) 14(1) Macquarie Law Journal 3-23.

32. R Forst, Contexts of Justice: Political Philosophy beyond Liberalism and Communitarianism. Trans JM Farrell (University of California Press, Berkeley 2002).

33. 'By "nature", I mean here, primarily, distinctions made between "enforceable" and not directly "justiciable" rights. By "number", I refer to the distinction between "enumerated" and "unenumerated" rights, the latter often articulated by practices of judicial activism. By "limits", I indicate here the scope of rights thus enshrined, given that no constitutional guarantee of human rights may confer "absolute" protection. The "negotiation" process is indeed complex; it refers to at least three distinct, though related, aspects: (1) judicially upheld definitions of grounds of restriction or regulation of the scope of rights; (2) legislatively and executively unmolested judicial interpretation of the meaning, content, and scope of rights; and (3) the ways in which the defined bearers of human rights chose or chose not to exercise their rights - this, in turn, presupposing that they have the information concerning the rights they have and the capability to deploy 
human rights, let alone of justice. Yet, TGJ do not go as far as to suggest that global social policies ought to be allowed to treat some climate change issues as 'moral free zones'. ${ }^{34}$ Further, most TGJ are divided on the issue of how far international law can cast the duties of justice on compatriots/co-nationals to assist strangers or nonnationals. TGJ are also divided on issues such as duties of reparation, affirmative action, and caritas.

Yet the Anthropocene era now upon us aggravates the tasks of global distributive justice. What duties of justice may we all owe to the very distant generations? Are these exhausted by the evolving regimes of "composite but differentiated responsibility'? Should the developed or historically 'over-developed' Euroamerican states and nations contribute more, in cash and kind, and disproportionately make reparation for past carbon economies and societies, or bear the future-disproportionate costs of moving away from these? I must say here in passing, and cryptically, that such justice obligations and transfers may well point towards the much deferred recognition of the need for historic redress for colonization and imperialism of the Westphalian, and contemporary, Cold War and war on 'terror' eras. What conceptions of distributive justice should be in evidence in international negotiations concerning 'rehabilitation' and 'resettlement' cost-sharing? How may we conceive of a planetary loyalty or species loyalty when world citizen loyalty remains so problematic? And how successfully may we stave off the indictment of anthropocentrism/anthropomorphism in devising a theory of climate change justice? I consider some of the issues below.

John Rawls famously declined the invitation to consider extending duties of assistance in the law of peoples on the ground of state autonomy or political culture (or beyond the 'cultures' of national, equal and sovereign, politics (or political life)) and resolutely refused to generalize A Theory of Justice's principles to a society of the world's peoples. His reluctance to universalize the difference principle (roughly put: inequalities are justified only if these contribute to the advantage of the worst off) has been overcome, as we know, by Charles Beitz and Thomas Pogge. We may safely reckon the advent of TGJ with their important works. ${ }^{35}$ Rawls' five types of international society and eight principles ${ }^{36}$ have been problematized in contemporary

them in various acts of living', U Baxi, Future (n 5) xxxiv, fn. 12. See also, U Baxi, 'Reinventing Human Rights in an Era of Hyperglobalization: A Few Wayside Remarks' in A Gearty and C Douzinas (eds), The Cambridge Companion to Human Rights Law (Cambridge University Press, Cambridge 2012) 150-70.

34. With the exception of D Gauthier who invented this term: see his Morals by Agreement (Oxford University Press, Oxford 1986); but see also his revised position in 'Twenty-Five On' (2014) 123 Ethics 601-24. See also, U Baxi, 'Market Fundamentalisms: Business Ethics at the Altar of Human Rights' (2005) 5(1) Human Rights Law Review 1-26; 'Human Rights Responsibility of Multinational Corporations, Political Ecology of Injustice: Learning from Bhopal Thirty Plus?' (2015) 1 Business and Human Rights Journal 21-40.

35. See CR Beitz, Political Theory and International Relations (Princeton University Press, Princeton, NJ 1979); TW Pogge, 'An Egalitarian View of Peoples' (1994) 23(3) Philosophy and Public Affairs 195-224. We ought equally carefully to attend now to the continental voice of Alberto de Luigi: see his 'Liberalism and the Principle of Difference: Rawls Tested by Larmore's Theory: Part 11', Centro Einaudi Laboratorio di Politica Comparata e Filosofia Pubblica, Working Paper-LPF n. 2: 2015.

36. John Rawls considered five types of political society and eight principles of the law of peoples. There are '... five types of domestic societies: the first of these is liberal peoples and the second, decent peoples. The basic structure of one kind of decent people has ... a 
literature. Moreover, while Rawls has only three principles of justice, Jürgen Habermas extends 'participation' as a basic human right in the way international lawyers conceive of 'core' rights. Despite their disagreement on how far cosmopolitan theorizing may extend, these thinkers conceive of human rights parsimoniously and decline to endorse the carnivalistic exuberance of the United Nations in the production of human rights.

\section{THEORIES OF ENVIRONMENTAL JUSTICE (TEJ)}

Writings on TEJ have displayed a lively concern with approaches to environmental jurisprudence and sustainable development, which both preceded and accompany TCJ. TEJ have both a domestic and international justice dimension. The former consists in statutory and judicial legal obligations that state and non-state agencies have increasingly to follow. Occasionally, where use and abuse of natural resources extends to two or more states or to the entirety of humankind, these obligations follow the course of human rights and environmental international customary law or treaty commitments.

The literature is vast and extends to all the basic problems of environmental justice: pollution of water and air, practices of dumping, waste-management, floods, drinking water, biodiversity, deforestation, tropical forests, mass ecological disasters, urbanization, etc. Environmental law has emerged as a response to some of these problems, which are partly attended to by legisprudence (the prudence concerning theory of legislation and regulation), jurisprudence (the prudence of judges and jurists), and democratic demosprudential adjudicatory leadership (the prudence of activist adjudicatory leadership of the nation). ${ }^{37}$ Added to these three kinds of prudence is the prudence of social movements and actors who explicitly or implicitly address the justice qualities of state-espoused sustainable development paradigms.

The diverse elements of that something that passes under the name of environmental law and justice is the subject matter of a 'rapidly expanding and diversifying literature' which raises the problems of integration of theoretical with empirical material and how to '... in particular, deal with evidence and justice concepts together'; these also 'lay out

\footnotetext{
"decent consultative hierarchy" and these people I call "decent hierarchical peoples"; the other kind of decent people is simply a category I leave in reserve. ... In addition, there are, third, outlaw states and, fourth, societies burdened by unfavorable conditions. Finally, fifth, we have societies that are benevolent absolutisms; they honor most human rights, but because they deny their members a meaningful role in the making of political decisions, they are not well-ordered'.

The principles of justice, rights, and social cooperation that peoples form comprise the following assemblage: ' 1 . Peoples are free and independent, and their freedom and independence are to be respected by other peoples. 2. Peoples are to observe treaties and understandings. 3. Peoples are equal and are parties to agreements that bind them. 4. Peoples are to observe a duty of non-intervention. 5. Peoples have a right to self-defense but no right to instigate war for reasons other than self-defense. 6. Peoples are to honor human rights. 7. Peoples are to observe certain specified restrictions in the conduct of war. 8. Peoples have a duty to assist other people living under unfavorable conditions that prevent their having a just or decent political regime', J Rawls, Law of Peoples (Harvard University Press, Cambridge, MA 1999) respectively at 81 and 30 .
}

37. See Baxi (n 31). 
a framework for understanding different elements of environmental justice claimmaking' in a 'systematic, analytical and ... structured pathway' - and a field constituted by diverse peoples' practices, social movements, state policy action/inaction. ${ }^{38}$ It has been suggested, and rightly so, that one needs in terms of a method the social science concept of 'framing' and, substantively, a concept of justice - in other words a concept of TEJ - to deal with the horizontal and vertical movements of claim-making. ${ }^{39}$ TEJ will, therefore, stress an 'environmental justice frame' which is 'not singular but flexible and dynamic' and is 'open to contextualization, as it moves across space and time' 40 and will fully cognize 'multiple spatialites', particularly avoiding 'unidimensional' geographies ${ }^{41}$ which fail to take this movement into account. Not just histories matter. Equally (what I call) the geographies of injustice play a decisive role in constituting notions of justice. ${ }^{42}$

What theoretical approach to justice informs TEJ? Clearly, unjustified and unjustifiable inequality in access to human rights to life and liberty count as unjust: environmental racism, the most extreme forms of which are represented by various apartheids, is considered now unacceptable $;^{43}$ so is ecological vulnerability as a form of social discrimination against the socially vulnerable - the condition of human rightlessness imposed by persistent denial of rights to food, water, clean air, shelter and housing, and health. Theoretically, as John Rawls identified it via the difference principle, the issue is not of inequality per se but that of justified inequalities from the standpoint of the worst-off and their expectations of justice from the social order. But, as TEJ have taught us, more than the conventional notions of distributive justice are at stake here: one needs to add to the notion of justice also that of fair and equal participation of the impoverished and the indigenous peoples and concepts of fair procedural justice. ${ }^{44}$ The notions especially of 'geographies of recognition and participation' 45 remain attractively important for further development.

Some TEJ theorists have thought about relating justice to 'sustainable development' - whether the last phrase is an oxymoron (or Baxi-moron) I do not know, but I have always said that in order to achieve 'sustainable development' one has to dare to articulate unsustainable thought! There is today a shift in emphasis: one

38. Walker (n 9) at xii.

39. Walker (n 9) at 33-7.

40. G Walker, 'Beyond Distribution and Proximity: Exploring the Multiple Spatialities of Environmental Justice' in Holifield et al. (eds) Spaces (n 9) at 33.

41. Walker (n 9) at 31.

42. See U Baxi, 'Some Newly Emergent Geographies of Injustice: Boundaries and Borders in International Law' (forthcoming, 2016) 23(1) Indiana Journal of Global Studies.

43. RD Bullard, Confronting Environmental Racism: Voices from the Grassroots (South End Press, Boston 1993); J Hamilton, 'Testing for Environmental Racism: Prejudice, Profits, Political Power?' (1995) 14 Journal of Policy Analysis and Management 107-32; L Westra and BE Lawson, Faces of Environmental Racism: Confronting Issues of Global Justice (Rowman \& Littlefield Publishers, Lanham, MD 2001).

44. See Walker (n 9), especially Chapters 3, 8, 9 and the literature cited therein; see also D Schlosberg, Environmental Justice and the New Pluralism: The Challenge of Difference in Environmentalism (Oxford University Press, New York 1998); A Dobson, Justice and the Environment: Conceptions of Environmental Sustainability and Theories of Distributive Justice (Oxford University Press, New York 1998).

45. Walker (n 9) at 37-9. 
talks about 'just sustainability' ${ }^{46}$ in a post-development era and agenda. ${ }^{47}$ It would take this present conversation far afield to explore the notions of 'sustainability'. However, suffice it to say here that sustainability is more a matter of polices of governance rather than an agendum of justice. The central notion is that which pertains to development; and development (howsoever we choose to describe its processes and programmes) always signifies a degree of destruction: the motto of developers everywhere is 'No development without destruction' and this entails the idea not merely that some degree of development is inevitable but that it is also just. If so, and, alternately put in terms of ethical meta-theory, some 'moral loss' is always entailed when we talk under the secular theologies of 'development', 'free markets' or 'post-development', the major question is then whether 'moral loss' is always just. The question always pertains to how much cost would/should the developees afford to pay and actually pay, and for how long. Do the measures of rehabilitation and resettlement ever make up for the loss of worlds? Is moral loss always to be borne as the costs of development by the communities of the worst-off in all societies? ${ }^{48}$

\section{THEORIES OF CLIMATE JUSTICE (TCJ)}

A considerable number of searching works on TEJ have raised, in the last two decades, questions of justice in regard to climate change, with (what may be called) justice in the Anthropocene problematic. Crucial to the discourse on theories of climate justice (TCJ) is the key notion of intergenerational justice (IJ). The eventually lethal persistence of $\mathrm{CO} 2$ gases that have a very long life requires the "elimination of emissions' as the goal of any climate-justice-based change policy. IJ postulates several duties of justice. How far the extant TGJ can be adapted or extended by TCJ poses a major issue for serious examination. TGJ, for example, only recently tackled the problem of redressing historic past wrongs. TCJ, however point out that the persistence of greenhouse gases is a past, present and future wrong that must somehow now be addressed.

\subsection{Climate justice theory and the Anthropocene problematic}

In the offing for the last two decades have been deepening questions of justice in regard to resilient climate change problems; on a high growth curve is the number of searching works on TEJ raising difficult theoretic questions concerning what may be called justice in the Anthropocene problematic. Climate change justice has been likened to a 'perfect moral storm' where many a converging factor adversely

46. J Agyeman, RD Bullard and B Evans, 'Joined-up Thinking: Bringing Together Sustainability, Environmental Justice and Equity' in J Agyeman et al. (ed), Just Sustainabilities: Development in an Unequal World, 1-16 (The MIT Press, Cambridge, MA 2003).

47. Center for Economic and Social Rights, A Matter of Justice: Securing Human Rights in the Post-2015 Sustainable Development Agenda (Center for Economic and Social Rights, New York 2013).

48. U Baxi, "What Happens Next is Up to You": Human Rights at Risk in Dams and Development' (2001) 16 American University International Law Journal 1507; U Baxi, 'Rehabilitation and Resettlement: Some Human Rights Perspectives' in HM Mathur (ed), Social Development Report: Development and Displacement (Oxford University Press, Delhi 2008). See also R Gordon, 'Unsustainable Development' in S Alam et al. (n 13) at 73. 
affects our 'ability to make the hard choices necessary to address it'. In a 'perfect moral storm, even if the difficult ethical questions could be answered, we might still find it difficult to act. For the storm makes us extremely vulnerable to moral corruption'. 49

TCJ are based on several premises. The first is that planet earth is in great distress, that her existing living/life systems are liable to destruction in the near future and that planet earth ought to be saved from total destruction. The second is that the burdens and responsibilities for saving the earth system ought to be borne by all peoples and nations that constitute the human earth community, although having regard both to the causes and consequences. Third, individual and collective human rights, and our notions of moral responsibilities and legal liability, need to be reinvented with a new perspective that respects 'common but differentiated responsibility'. ${ }^{50}$ Fourth, we ought to seek TCJ forms that avoid anthropomorphism. ${ }^{51}$ Fifth, TCJ, while

49. SM Gardiner, 'A Perfect Moral Storm: Climate Change, Intergenerational Ethics and the Problem of Moral Corruption' (2006) 15 Environmental Values 397-413 at 398. But see D Jamieson 'Jack, Jill, and Jane in a Perfect Moral Storm' (2013) 3(1) Philosophy and Public Issues (New Series) 37-53. Jamieson, I think rightly, maintains that 'we do not have adequate norms and values that motivate us to address climate change. This is a "profound ethical failure" - or to use another of Gardiner's descriptions, a "tragedy" - but it is not the same kind of failure or tragedy as failing to live up to one's principles. In my opinion, the really profound moral challenge of climate change consists in formulating and implementing new moral norms and concepts that are adequate to the problems we face in this unprecedented period in human history' (at 38). But he is in deep agreement with Gardiner in one respect: 'Our failure to act efficaciously in response to climate change indicates a crisis of agency, both in ourselves and in our institutions. Perhaps the greatest challenge of this century is to reconstruct and instantiate forms of individual and collective agency that will enable us to manage the problems that we face to live meaningful lives in a rapidly changing world' (at 53). See, for some approaches to TCJ, P Baer and T Athanasiou, 'Frameworks \& Proposals: A Brief, Adequacy and Equity-based Evaluation of Some Prominent Climate Policy Frameworks and Proposals' (2007) Global Issue Papers No. 30, Berlin, Heinrich Böll Stiftung; D Birnbacher, 'Climate Responsibility as a Distributional Issue' (2010) 32 Analyse und Kritik 25-37; J Broome, 'Discounting the Future' (1994) 23 Philosophy and Public Affairs 128-56; S Caney, 'Environmental Degradation, Reparations, and the Moral Significance of History' (2006) 37(3) Journal of Social Philosophy 464-82; 'Justice and the Distribution of Greenhouse Gas Emissions' (2009) 5(2) Journal of Global Ethics 125-46; 'Climate Change and the Future: Discounting for Time, Wealth, and Risk' (2009) 40(2) Journal of Social Philosophy 163-86; M Kowarsch and A Gösele 'Triangle of Justice' in O Edenhofer et al. (eds), Climate Change, Justice and Sustainability: Linking Climate and Development Policy (Springer Science+Business Media, Dordrecht 2012) at 73-88; M Gardiner, SM Caney, D Jamieson and H Shue (eds), Climate Ethics: Essential Readings (Oxford University Press, Oxford 2010); PG Harris, World Ethics and Climate Change: From International to Global Justice (Edinburgh University Press, Edinburgh 2009); E Posner and D Weisbach, Climate Change Justice (Princeton University Press, Princeton 2010); H Shue, The 'Unavoidability of Justice' in A Hurrell and B Kingsbury (eds), The International Politics of the Environment: Actors, Interests and Institutions (Clarendon Press, Oxford 1992) at 373-97; S Vanderheiden, Atmospheric Justice: A Political Theory of Climate Change (Oxford University Press, New York 2008).

50. L Rajamani, 'The Increasing Currency and Relevance of Rights-Based Perspectives in the International Negotiations on Climate Change' (2010) 22(3) Journal of Environmental Law 391-429; see also, L Rajamani, Differential Treatment in International Environmental Law (Oxford University Press, Oxford 2006).

51. A Grear, 'Deconstructing Anthropos: A Critical Legal Reflection on "Anthropocentric": Law and Anthropocene "Humanity" (2015-05-20) Law and Critique 1-25, published online 
maintaining civic and cordial relations with the approaches and languages of TGJ and TEJ, ought more directly to address the general and the concrete other, these have allied but also different concerns: together with the survival of the planetary Earthsystem as such, TCJ have to remain vigilant about small island developing state concerns of relocation and resettlement, as well as aid and climate refugees $;{ }^{52}$ in this sense, TCJ approaches ought to offer considerations of justice in a new key. Here, the argument is that refined utilitarian, global cosmopolitan, communitarian, civic and republican approaches ${ }^{53}$ and considerations of justice are in place, but these do not encourage and sustain new planetary loyalty and the political urgency that global climate change, in its resilience, now summons. The overarching factor and context now is to discover new ways of building our concerns with human well-being, capabilities and flourishing in ways that enhance species survival. Sixth, significant social movements have offered new concepts and practices that TCJ eagerly deploy - and this connectedness is both relatively novel and decidedly fruitful. Seventh, without being exhaustive, most TCJ approaches analyse and relate to the changing climate negotiations and national policy and adjudicatory needs, perspectives and postures; never before was the imperative to relate theory to practice felt to be so pressing.

I highlight a few of these features here, but do not directly comment on all of them. As concerns the fourth feature, the difficulty, in my view, lies in the assumption of justice that human life in 'nature' (and nature as we know it) should go on indefinitely and so should planet earth to whom we owe duties of basic care. Without this assumption of justice no theory about climate justice will be possible, and while anthropomorphism can and should be cured, I maintain that the justice assumption is logically necessary, though not by itself sufficient unless extended to the normative protection of all lifeforms and lifeworlds on planet Earth - and life wherever found in other galaxies. But is a theory of global change and global climate justice to be construed as a theory of inter-galactic justice? None of the extant climate change conceptions, in theory or movement, extend this far.

We may endorse, in any event, Anna Grear's claim that we need a more nuanced notion of what may constitute anthropomorphism, which 'must explicitly engage with the oppressive hierarchical structure of the anthropos itself - and should directly address its apotheosis in the corporate juridical subject that dominates the globalized

DOI 10.1007/s10978-105-9161-0. See also A Grear, 'Towards "Climate Justice"? A Critical Reflection on Legal Subjectivity and Climate Injustice: Warning Signals, Patterned Hierarchies, Directions for Future Law and Policy' (2014) Journal of Human Rights and the Environment 103-33. Grear ends the former article by posing the question that should engage us all: 'There, in short, is a vital need to replace the hegemonic assumptions of anthropos with criticallyinformed, reflexive, epistemically humble and renewing engagements with the question of who "we" are in the Anthropocene age. How, with a transformed, non-universal, non-essentialist notion of the "human" as a diverse entanglement with nature-culture might "we" and "nonhuman others" co-inform a liberatory, restorative ontology, epistemology and ethics adequate to Anthropocene futures - and most especially to the need for an injustice-sensitive set of practices faithful to delivery of inclusion, compassion and resilience in a climate-threatened world?'.

52. See M Lister, 'Climate Change Refugees' (2014) 17(5) Critical Review of International Social and Political Philosophy 618-34 (2014).

53. Forst (n 32); also see S Besson and JL Ma, Legal Republicanism: National and International Perspectives (Oxford University Press, Oxford 2009). 
order of the Anthropocene age'. ${ }^{54}$ Not so much focusing on the 'oppressive hierarchical structure of the anthropos itself', and appealing instead to Hume's notion of 'indirect passions', Mary Warnock recently proposed that our desire to save the planet is invariably 'in terms of what we value'; feelings of shame and guilt accompany unjust destruction: 'We want to save the planet because we love the universe in which we live; and because we deeply fear what we seem ineluctably [to be] doing to destroy what we love. Nothing will do instead of what we now have and what we are in danger of losing, 55

The difficulties with human-rights-based approaches have much in common with those encountered in TGJ. There is virtually no human rights law or jurisprudence commanding any planetary loyalty required to sustain this loyalty or even minimum human rights responsibilities in corporate governance or the ways of doing business that respect core human rights. ${ }^{56}$ But there is also no doubt, as Rajamani says, that 'human rights approaches, taken in their entirety, have the potential to bring much needed attention to individual welfare as well as to provide ethical moorings in inter-governmental climate negotiations currently characterized by self-interested deal-seeking' ${ }^{57}$ No doubt, further, such an approach entails the formation of 'benchmarks' for adjudging state actions which may increase the accountability of authorities, and 'may also offer additional criteria for the interpretation of applicable principles and obligations that states have to each other, to their own citizens, and to the citizens of other states in relation to climate change'. ${ }^{58}$

The Male' Declaration on the Human Dimension of Global Climate Change invoked 'the fundamental right to an environment capable of supporting human society and the full enjoyment of human rights', and articulated an explicit concern:

climate change has clear and immediate implications for the full enjoyment of human rights including inter alia the right to life, the right to take part in cultural life, the right to use and enjoy property, the right to an adequate standard of living, the right to food, and the right to the highest attainable standard of physical and mental health. ${ }^{59}$

54. Grear, 'Deconstructing Anthropos' (n 51) at 2. See also Jeremy Baskin, 'Paradigm Dressed as Epoch: The Ideology of the Anthropocene' (2015) 24 Environmental Values 9-29. 55. Elgar Blog, 2 July 2015 <http://elgarblog.com/2015/07/02/nothing-will-do-instead-ofwhat-we-now-have-and-what-we-are-in-danger-of-losing-mary-warnock-on-ownershipresponsibility-and-a-planet-in-peril/> accessed 25 June 15; and her Critical Reflections on Ownership (Edward Elgar, Cheltenham 2015).

56. See U Baxi, 'Human Rights Responsibility of Multinational Corporations' (n 12).

57. See L Rajamani, 'The Increasing Currency and Relevance of Rights-Based Perspectives in the International Negotiations on Climate Change' (2012) 22(3) Environmental Law 391-429 at 391 .

58. Ibid at 395. See also S Adelman, 'Human Rights and Climate Change' in Stephen Humphreys (ed), Human Rights and Climate Change (Cambridge University Press, Cambridge 2010) 159-80.

59. This extremely valuable Declaration by the representatives of the Small Island Developing States meeting in Male' from 13 to 14 November 2007, is known as Male' Declaration on the Human Dimension of Global Climate Change, available at $<$ http://www.ciel.org/Publications/ Male_Declaration_Nov07.pdf $>$. See, further, S Caney, 'Climate Change, Human Rights and Moral Thresholds', in S Humphreys (ed), Human Rights and Climate Change (Cambridge University Press, Cambridge 2010) 69-90; D Bell, 'Does Anthropogenic Climate Change Violate Human Rights?' (2011) 14(2) Critical Review of International Social and Political Philosophy 99-124. 
The notion of biocultural rights is fascinatingly supple; it is principally focused on the rights of indigenous peoples and communities but also provides a more general framework for TEJ. The inherently complex notion of 'biocultural rights' however, displays many ambivalences and dualities ${ }^{60}$ that need to be resolved to serve TCJ more fully.

All this goes beyond human rights to a 'green future' and also far beyond law and jurisprudence to the moral idea of human rights. We need to rethink both the lex lata and de lege feranda of international law as well as revisit the basis of the law of peoples. For example, capitalist accumulation rests on the idea of doing harm to others, both as a moral and legal right. I indicated in 1987 that human rights in class-divided societies are ultimately bourgeois rights, based on the freedom of property and transaction, and entail a 'lawful' and justified right to harm others. ${ }^{61}$ In meta-ethical theory, this problem is discussed as a 'right to do a moral wrong', ${ }^{62}$ and this right, in my belief, also extends to a human right to do a human rights wrong. In a capitalist and market society and economy, where exploitation is the rule and emancipation a utopia, the human right to a free competition signifies a right to cause harm to innocent and vulnerable others.

Rajamani observes further that, first, climate protection could be brought within the context of 'the existing human right in relation to the environment, litigated in several national and international fora, and thus enforced in discrete cases. Second, a human rights optic could be applied to climate impacts. The latter is by far the less concrete yet more ambitious approach in that it seeks a reframing of the climate problem which would draw nations towards ever more stringent actions. In the latter, the value-laden language and rhetoric of human rights is pressed into service to stress the urgency of climate change and to catalyze multilateral action on it. It is this endeavour in which some Parties in the climate negotiations are engaged. However, the scope and limits of the former are also worth exploring ...', Rajamani (n 57) at 406. But the frustration of small island states is also striking and aggravates the problems of TCJ. These 'range from the ICJ case to employing an obscure dispute settlement provision of the U.N. Framework Convention on Climate Change (UNFCCC). But, those involved say, the single biggest thing holding back poor nations is their near-total dependency on big emitters for development, trade and, increasingly, money to adapt to climate change'. As a 'sad fact' of life, these small communities are heavily 'dependent on foreign aid ... that hold them back from making these types of claims, and it's a tragedy', L Friedman, 'Island States Mull Risks and Benefits of Suing Big Emitters', E\&E reporter: Climate Wire Friday, 16 November 2012. See also A Korman and G Barcia, 'Rethinking Climate Change: Towards an International Court of Justice Advisory Opinion' (2012) The Yale Journal of International Law Online 35-42; DB Hunter, 'The Implications of Climate Change Litigation for International Environmental Law-Making' (2007) WCL Research Paper No. 2008-14, available at SSRN <http://ssrn.com/ abstract=1005345>; M Gagain, 'Climate Change, Sea Level Rise, and Artificial Islands: Saving the Maldives' Statehood and Maritime Claims Through the "Constitution of the Oceans" (2012) 23(1) Colorado Journal of International Environmental Law \& Policy 78-120.

60. This issue may not be pursued here: but see KS Bavikette, Stewarding the Earth: Rethinking Property and the Emergence of Biocultural Rights (Oxford University Press, Delhi 2014) and see the lively discussion in the Journal of Human Rights and the Environment (2015) 6(1), particularly the contribution of Giulia Sajeva at 30-54.

61. U Baxi, 'From Human Rights to the Right to Become Human: Some Heresies' (1986) 13 India International Centre Quarterly 185.

62. I am currently working on this important subject and struck by the paucity of research on the subject. See, for a sustained liberal philosophy discussion, J Waldron, 'A Right to Do Wrong' (1981) 92 Ethics 21; OJ Herstein, 'Defending the Right to Do Wrong' (2012) 31 Law and Philosophy 343. 
The common law of torts and contracts, private international law, and the 'soft' law governing the human rights responsibilities of international business, ${ }^{63}$ provide leading examples. The struggle of legisprudence ${ }^{64}$ is always to impose reasonable limitations on the right to lawful and ethical harm, but the right remains the very core of capital accumulation. The problems are aggravated when we consider climate change as a series of discrete environmental disasters affecting the 'disappearing states', or similar others (such as women, first nations peoples, children, the wounded, sick or senior citizens, those confined within total institutions, or differently abled peoples) and the precariousness of democratic legitimacy promoting free markets within and across borders.

The moral right to harm and to hurt has always been questioned by the violated, erroneously called 'victims'. Indeed, there are no fairy tales here: it has been rightly said that the 'best-selling author Stephen King will find himself at home in the world of tort law. It is replete with horror stories' ${ }^{65}$ While risks have to be allocated in an industrial society, ${ }^{66}$ now in the 'market civilization' ${ }^{67}$ 'normal accidents ${ }^{68}$ will happen: TCJ alert us concerning earth science facts about climate change and urge us all that the time to act in concert is now.

This said, the recent effort by Andrew Linklater must be noted here: he traces the histories of 'harm narratives' of the last two centuries across the world in order 'to understand whether, or how far, the modern world has made progress in making harm a key moral and political question for humanity as a whole'. ${ }^{69}$ He distinguishes

63. See Baxi, Future (n 5) Chapters 8 and 9.

64. For this discursive formation see L Wintgens, Legisprudence: A New Theoretical Approach to Legislation (Hart Publishing, Oxford 2002); The Theory and Practice of Legislation: Essays in Legisprudence (Ashgate, London 2005); and 'Legitimacy and Legitimation from the Legisprudential Perspective' in LJ Wintgens and P Thion (eds), Legislation in Context: Essays in Legisprudence (Ashgate, London 2007) 3, 4.

65. PA Bell and J O'Connell, Accidental Justice: The Dilemmas of Tort Law (Yale University Press, New Haven, CT 1997) xi.

66. PW Huber alerts us that tort adjudicatory polices 'fail to operate as a rational ordering device for selecting among good and bad public risks' and his counsel also extends to public policy and legislation which all too often rest on 'the Panglossian belief that we already reside in the safest of all possible worlds and the Malthusian conviction that the future has nothing to offer but a snake', from his oft-cited article 'Safety and the Second Best: The Hazards of Public Risk Management in the Courts' (1985) 85(2) Columbia Law Review 277-337 at 306-308, 311, 318. See also his Liability: The Legal Revolution and Its Consequences (Basic Books, New York 1990).

67. S Gill, 'Globalization, Market Civilization, and Disciplinary Neoliberalization' (December 1995) 24(3) Millennium - Journal of International Studies 399-423; see also 'Petro-market Civilization' (2012) at <http://philosophersforchange.org/2012/11/20/petromarket-civilization/>; B Bowden and L Seabrooke, 'Market Civilization and its Clash with Terror' (2002/03) 27 International Security 5-29.

68. The notion of 'normal accidents' intrigues, when thought of from the standpoint of those upon whom is the burden of bearing the harms caused by it, often intergenerational as in the Bhopal catastrophe; the problematic of long-term effects and harm is poignantly posed by the resilience of the facts and futures of climate change. For sociological thought, see C Perrow, Normal Accidents: Living with High-Risk Technologies (Princeton University Press, Princeton, NJ 1999). But see A Silvast and I Kelman, 'Is the Normal Accidents Perspective Falsifiable?' (2013) 22(1) Disaster Prevention and Management 7-16.

69. A Linklater, The Problem of Harm in World Politics: Theoretical Investigations (Cambridge University Press, Cambridge, 2011) at 5 (hereafter simply referred to by author). 
between 'concrete' harm and 'abstract' harm; the former comprises 'the harm that particular human agents intentionally inflict on specific others who are placed outside the former's moral community because of religious, racial or other supposedly morally decisive characteristics', while 'abstract harm' is the harm unintentionally inflicted upon persons, groups or the global commons. ${ }^{70}$

Because 'Every functioning society must possess some concept of harm in an inventory of moral concepts that address the problem of how to regulate social behaviour $^{71}$ (proving thus to be a more universal measure than the ideas of human rights or democracy), ${ }^{72}$ the idea of transnational harm assumes salience in contemporary times. Notions of harm, transnational harm and harm narratives have changed according to time, place and circumstance, but:

the 'harm narrative' that may come to command greater support in different parts of the world tends towards a negative utopianism - to the aspirations to see an end to particular systems of domination, oppression and exploitation rather than to try and breathe new life into one of the discredited visions of human reconciliation that depended on a naïve faith in perfectibility. ${ }^{73}$

And this 'narrative of partial progressions over the past two centuries' is also the story of 'different forms' of harm, encouraging the 'development of universal structures of consciousness with significant cosmopolitan potential' ${ }^{74}$ Linklater is right to name the development of Cosmopolitan Harm Conventions (CHCs) ${ }^{75}$ and to endeavour to take more fully into account Marxian and Critical Theory, and we should also note that his very important project is unfolding into a historical and philosophical trilogy.

Even so, at least from a TCJ perspective, it is not too early to interrogate his typology, and sociology, of moral harms. The categorization, though not rigid, in principle impermissibly defers public and policy attention to 'abstract' harms. Uncannily, the analysis that Linklater offers obscures the distinction drawn earlier by Judith Shklar between 'injustice' and 'misfortune': 'If the dreadful event is caused by the external forces of nature, it is a misfortune and we must resign ourselves to our suffering. Should, however, some ill-intentioned agent, human or supernatural, have brought it about, then it is an injustice and we may express indignation and outrage'. ${ }^{76}$ But Shklar also warned that the dichotomy could be misleading: She writes; ' $[\mathrm{t}] \mathrm{hat}$ something is the work of nature or of an invisible social hand does not absolve us from the responsibility to repair the damage and to prevent its recurrence as much as possible'. ${ }^{77}$ Ultimately, 'what is treated as unavoidable and natural, and what is

70. Ibid at $140-2$.

71. Ibid at 6.

72. 'The principal sociological objective is to understand the extent to which different international systems made progress in institutionalizing a harm principle that can be said to be immanent in all societies because they all have mechanisms for protecting (at least high status) members from unnecessary harm', ibid at 44 .

73. Ibid at 264 .

74. Ibid at 261.

75. See also A Linklater 'Citizenship, Humanity, and Cosmopolitan Harm Conventions' (July 2001) 22(3) International Political Science Review/Revue internationale de science politique 261-77.

76. See generally JN Shklar, The Faces of Injustice (Yale University Press, New Haven, CT 1990) at $1-2$.

77. Ibid at 50 . 
regarded as controllable and social, is often a matter of technology and of ideology or interpretation' ${ }^{78}$ Because the 'perceptions of victims and of those who, however remotely, might be victimizers, tend to be quite different', ${ }^{79}$ issues of justice/injustice indwell that difference. This is also the wisdom of TCJ.

It may justly be said that the notion of abstract harm as unintentional act or omission $^{80}$ is deeply problematic for disassociating agency from harm; if the 'harm' is unintentional (whether commission or omission) then this amounts to an example of causeless effect, which in turn ends up in human rights impunity for many agents of harm who are themselves harm-specialists.

The Hippocratic injunction, primum non nocere (above all, do not harm) ought to extend to all agents (state as well as non-state) and render this principle as the cornerstone of TCJ - that is, the moral idea of human rights, not impunity for those who hurt and harm, whether in intention or result.

\subsection{Intergenerational justice (IJ)}

Crucial to the discourse on climate justice theory (TCJ) is the key notion of intergenerational justice (IJ, hereafter). The eventually lethal persistence of CO2 gases, which have a very long life, requires 'elimination of emissions' as the goal of any climate-justice-based global change policy. IJ postulates a duty of justice. How far the extant TGJ can be adapted or extended by TCJ poses a major issue for serious examination. TGJ, for example, have only recently tackled the problem of redressing historic past wrongs. ${ }^{81}$ TCJ, however, point out that the persistence of greenhouse gases is a past, present and future wrong that must now be somehow addressed.

Approaches to TGJ as well as TCJ are essentially of the kind to which Edmund Burke gave an articulation of society in terms of 'partnership'. For Burke society is:

a partnership in every virtue and in all perfection. As the ends of such a partnership cannot be obtained in many generations, it becomes a partnership not only between those who are living, but between those who are living, those who are dead, and those who are to be born. $^{82}$

The nature of this partnership in TCJ is moral and ethical compared with the forms that aggregations of capital may take (whether the joint-stock company, partnership, cooperative society, multinational or transnational enterprise or entity or any other association). TCJ postulate the teleological 'ends of partnerships' in many languages and metaphors (cosmological, theological, indigenous peoples, feminist and other languages) but the goal remains the same: the human obligation to save the planet, its biodiversity and the human species.

But here the agreement ends, and questions begin about what precise human rights obligations we owe to each other and to distant others. The TCJ notion of

78. Ibid.

79. Ibid at 1.

80. See Linklater (n 69) at 151-3, 175.

81. See infra note 82 .

82. E Burke, Reflections on the Revolution in France (Penguin, London 1968) 194-5. Of course, this tract stands for anti-revolutionary change; as is well known, Burke preferred 'growth by insensible degrees'. 
intergenerational justice varies dramatically. As pointed out, for example, by Tremmel, ${ }^{83}$ the notions of generation address levels of mitigational allocation, burdens or responsibility: 'intergenerational' will accordingly refer to the present generation; to intrageneration (which implies the burdens to be borne in this generation between and among the developed and developing centuries and the rich and the poor nationally); and international (implying mitigational responsibilities to be shared by states inter se based on historical emissions or those since the 1990s, or 'other factors' as may emerge during climate negotiations).

Janna Thompson has written with rare insight on the problem of historical injustice and the forms of reparation. ${ }^{84}$ Her contribution, as far as TCJ are concerned, is to highlight ways in which John Rawls' insistence on the application of affirmative action to three generations may also extend beyond affirmative action to past injustices. ${ }^{85}$ However, the question arises whether the phenomenon of climate change entails the problematic of infinite justice - duties to very different and very distant generations. Is an infinite justice obligation any ethical obligation at all?

There are, however, further difficulties with the paradigm of historical justice as applied in the context of climate change. The first may be called epistemological difficulty; climate science did not exist in the times of first modernity and industrial revolution. Conjoint with the idea that we cannot harm others if we do not even know that our action will harm others, Tremmel fixes the date of climate science with the first report of the IPCC in 1990: 'for the sake of justice, countries are accountable for their entire emissions since 1990. This should occur by means of overshooting-rights for a limited time granted to the South from the North' ${ }^{86}$ He poses thus not just the issue of when climate change science can be said to be born but also raises the important question as to whether we can harm when we could not be said to sense or to know the harm.

83. JC Tremmel, A Theory of Intergenerational Justice (Routledge, London 2009); see also JC Tremmel, 'Climate Change and Political Philosophy: Who Owes What to Whom' (2013) 22(6) Environmental Values 725-49; BH Weston, 'Climate Change and Intergenerational Justice: Foundational Reflections' (2008) 9(3) Vermont Journal of Environmental Law 375-430. Tremmel's article, 'Climate Change and Political Philosophy', aspects of which we consider below, attempts most rigorously 'to end with a synthesis of the arguments into what can be considered to be the most reasonable and fairest approach to the politics of climate change on a global scale' (at 726).

84. J Thompson, 'Injustice and the Removal of Aboriginal Children' (2000) 2 Australian Journal of Professional and Applied Ethics, 2-13; 'Historical Injustice and Reparation: Justifying Claims of Descendants' (2001) 112(1) Ethics, 114-35; Taking Responsibility for the Past (Polity, Cambridge 2003); 'Apology, Justice and Respect: A Critical Defense of Political Apology' in M Gibney (ed), The Age of Apology: Facing Up to the Past (University of Philadelphia Press, Philadelphia 2008); Intergenerational Justice: Rights and Responsibilities in an Intergenerational Polity (Routledge, Abingdon 2009); M Thaler 'Just Pretending: Political Apologies for Historical Injustice and Vice's Tribute to Virtue' (2012) 15(3) Critical Review of International Social and Political Philosophy 259-78.

For narratives of the apologies offered by states, and some non-state actors, see N Mills, 'The New Culture of Apology' (2001) 48(4) Dissent 113-16; and M Cunningham, 'Saying Sorry: The Politics of Apology' (1999) 70(3) Political Quarterly 285-93.

85. See MS Williams, 'Justice Toward Groups: Political Not Juridical' (1995) 23(1) Political Theory 67-91.

86. JC Tremmel, 'Climate Change and Political Philosophy: Who Owes What to Whom?' (n 83) at 747 . 
The second difficulty relates to demographic argument: population growth increases the numbers of people hurt or harmed by climate change. Tremmel concludes his analysis on this score by insisting that 'population changes from 1990 should be taken into account in a climate treaty. 1990 is the year from which climate change - and therewith the contribution of population growth to climate change as well - became known to the global public'. ${ }^{87}$ Several questions arise here. Is 'development the best contraception', as the former Prime Minister of India Indira Gandhi once said, or a specifically women-friendly 'development'? ${ }^{88}$ How do we study runaway growth in the world's population and the differential impacts of climate change? Why is the 'principle of equal sacrifice' ${ }^{89}$ here not a principle of Justice? And what kind of biopolitics/biojustice is this where we proceed to measure human and social suffering by the politics of numbers? Is the suffering of adversely affected peoples any the less because of population growth? Or is growth thus an independent variable unrelated to the facts, policy or justice of climate change?

Is there a moral obligation on the North to compensate the global South for assaulting the atmosphere and changing the climate? Is something called 'retributive compensation' permitted in the case of climate change? Most thinkers on climate change justice take the view that it does not. ${ }^{90}$ Tremmel explicitly advocates the view that 'the idea of justice is not suitable for this cause, but that supererogatory duties demand us to compensate the South for the North's excessive use of atmospheric resources before 1990', and he goes on to say that:

Morality is not exhausted merely in complying with mandates of justice. The scope of morality also encompasses good-naturedness, benevolence, sympathy, compassion, altruism, generosity and other such qualities. But of course there is no moral obligation to these supererogatory duties, whereas it would be immoral not to fulfil obligations of justice. ${ }^{91}$

If this position holds, what arises is not an historical justice problem but that of the preferred method of social explanation: who, how and why is one to decide on whether aspects of morality are enforceable or not? Conceding that not all good things are morally required, it is still arguable that claims for taking responsibility for the past are not 'supererogatory' but constitute the very foundations of TCJ. Methodological individualism - that is making an ethical argument from single individual cases - does not necessarily embrace harms done to sections of humanity, much less to ecological systems as a whole. ${ }^{92}$

87. Ibid at 746.

88. See B Patil, Communication Strategies in Reproductive Health (Discovery Publishing House, Delhi 2009).

89. D Miller, 'Global Justice and Climate Change: How Should Responsibilities be Distributed?' (2009) 28 Tanner Lectures on Human Values 117-56.

90. See Miller (n 89); J Miller and R. Kumar (eds), Reparations: Interdisciplinary Inquiries (Oxford University Press, Oxford 2007); S Caney, 'Cosmopolitan Justice, Responsibility and Global Climate Change' (2005) 18 Leiden Journal of International Law 747-75 (2005); 'Climate Change and the Duties of the Advantaged' (2010) 13(1) Critical Review of International Social and Political Philosophy 203-28.

91. Tremmel, 'Climate Change and Political Philosophy: Who Owes What to Whom' (n 83) at 745 .

92. It will take this essay far afield to revisit debates and discussion on this method for 'interpretative' social science, which led to explanations of collective behaviour and several rounds of debates among social scientists. See eg J Alexander, The Micro-Macro Link (University of 
The towering issue uniting, as it were, the policy-makers, negotiators and theorists of global and climate change justice is to find intersubjective but normatively shared grounds for postulating certain duties or obligations of global climate justice. These grounds have to rest on a new ethics that insists on a harm avoidance principle. In Peter Lawrence's words it prescribes that the 'current generation, particularly those in positions of power, have an ethical obligation to refrain from action which has a high probability of causing serious harm to the basic interests and core human rights of (1) the current generation and (2) the future generations' ${ }^{93}$ Calling this a 'harm avoidance principle' - indeed, a long ethical and social theory lineage in European as well as non-European thought and theory - Lawrence draws our attention to the fact that a harm avoidance principle has the merit of consistency with the 'polluter pays' principle and the precautionary principle. ${ }^{94}$ And the principle also seems workable enough to give urgency, and otherwise inform, the present UN climate negotiations. The need for a binding climate change treaty can no longer be denied. ${ }^{95}$

The harm here is conceived of as extending to a large number of future persons and generations. And there are further problems, as pointed out particularly by Stephen Gardiner. He demonstrates, first, that 'climate change is not a static phenomenon' and in 'failing to act appropriately, the current generation does not simply pass an existing problem along to future people, rather it adds to it, making the problem worse'. The costs are the 'costs of coping with climate change': failing to act now increases the magnitude of future climate change and so its effects while 'it increases mitigation costs: failing to act now makes it more difficult to change because it allows additional investment in fossil fuel based infrastructure in developed and especially less developed countries'. Social inaction and indifference 'raises transition costs, making future change harder than change now'. Finally, 'and perhaps most importantly, the current generation does not add to the problem in a linear way. Rather, it rapidly accelerates the problem, since global emissions are increasing at a substantial rate. The total carbon dioxide emissions have more than quadrupled since $1950 \ldots .{ }^{96}$ In other words, the harm is already constituted by

California Press, Berkeley 1987), J Elster, Nuts and Bolts for the Social Sciences (Cambridge University Press, Cambridge 1989); G Hardin, 'The Tragedy of the Commons' (1968) 162 Science 1243-8; Collective Action (Johns Hopkins University Press, Baltimore 1982); S Lukes, 'Methodological Individualism Reconsidered' (1968) 19(2) The British Journal of Sociology 119-29; T Parsons, The Structure of Social Action, 2 volumes (Free Press, New York 1937); K Popper, The Open Society and Its Enemies (Routledge \& Kegan Paul, London 1996); L Udehn, Methodological Individualism (Routledge, London 2001).

93. P Lawrence, Justice for the Future Generations: Climate Change and International Law (Edward Elgar, Cheltenham 2014) 33 (referred to hereafter by the author).

94. Ibid at 35.

95. Lawrence (n 93) raises some important objections to the proposed principle and discusses various other approaches to climate justice (at 35-63) with which I do not engage here. He seems to draw a distinction between human rights oriented/based CCJ approaches and 'environment/climate' based rights concerns. While not hostile to 'deep ecology approaches', he is moved to endorse 'practical pluralism' which encourages building on the 'human centered ethical and justice theories', which is 'less controversial' and relies on 'human rights to life, health, and subsistence, which are adequate in generating ethical obligations towards future generations', at 61-2.

96. Gardiner (n 49) 405. 
leaving the matter of setting things right to future generations; in the present state of knowledge, this harm is astronomical by most estimates.

But the harm also seems infinite. If it is morally right, under specified circumstances to harm others (as proponents of a human right to do a moral, even human rights, wrong have to maintain) then future generations have a human right to cause justified harm to other generations. Gardiner, for example, is able thus to raise the following question: If the ground of self-defence is permitted morally under some circumstances, "such circumstances may arise in the climate change case'. Hence, the claim that:

one way in which generation A might behave badly is by creating a situation such that generation $\mathrm{D}$ is forced to call on the self-defence exception and so inflict extra suffering on generation F. Moreover, this problem can become iterated: perhaps generation $\mathrm{F}$ must call on the self-defence exception too, and so inflict harm on generation $\mathrm{H}$, and so on. ${ }^{97}$

One may question the possibility, or even the probability, of continuations of conceptions of justice that permit a lawful right to harm innocent others; but assuming that these would continue into the future, the human right to cause harm to infinite generations will also continue. And if there are no duties, and responsibilities, to avoid lawful harm to the innocent and vulnerable others, how does the obligation to act now, in this 'perfect moral storm', arise at all?"

97. Ibid at 407.

98. The feminist theory and movement approaches to TGJ, which need to be translocated to TCJ, require a further extended analysis. What passes as 'ecofeminism' has generated a great deal of interest and analysis concerning women and climate change: see for a literature survey, 'Gender and Climate Change: Mapping the Linkages: A Scoping Study on Knowledge and Gaps' (Prepared for the UK Department for International Development by A Brody, J Demetriades and E Esplen, BRIDGE, Institute of Development Studies March, 2008); S Williams and R Masika, Editorial in 'Gender, Development and Climate Change' (2002) 10(2) Oxfam Gender and Development Journal 2-9. These indicate knowledge deficits and the need to overcome these as well as the urgency of more gender sensitive policies; the task of feminist theories of climate justice (FTCJ) is more complex. It is to provide theoretical bases or reflections on global change polices in the Anthropocene and critiques of extant theories of global justice as being patriarchal in nature, as well as exploring justice theories as laying the base for migration and resettlement polices for disappearing states and communities in the Anthropocene era and prescribing standards of justice in a post-carbon era. This last brings also to fore the concern of whether we need yet another wave of feminist theory: see on the first three waves, S Gillis, G Howie and R Munford (eds) Third Wave Feminism: A Critical Exploration (Palgrave Macmillan, Houndmills 2007); R Hague, 'Between the Waves: Currents in Contemporary Feminist Thought' (2014) Political Studies Review 1-11, doi: 10.1111/1478-9302.12047; BA Bee, J Rice and A Trauger, 'A Feminist Approach to Climate Change Governance: Everyday and Intimate Politics' (2015) 9(6) Geography Compass 339-350.

I have found fascinating and promising for FCJT the work of JK Gibson-Graham focusing on diverse economies: 'A Feminist Project of Belonging for the Anthropocene' (2011) 18(1) Gender, Place and Culture 1-21; A Postcapitalist Politics (University of Minnesota Press, Minneapolis 2006); The End of Capitalism (As We Knew It): A Feminist Critique of Political Economy (Blackwell, Cambridge, MA 1996); JK Gibson-Graham, S Resnick and R Wolff (eds), Class and its Others (University of Minnesota Press, Minneapolis 2000). To this must be added some 'companion' work: see eg L McDowell, Capital Culture: Gender at Work in the City (Blackwell, Oxford 1997); see also R Nagar, V Lawson, S Hanson and L McDowell, 'Locating Globalization: Feminist (Re)readings of the Subjects and Spaces of Globalization' 
And, yet further, if the obligations of justice are to extend to civil society (widely conceived as including not just the dominant and hegemonic but all actors) and to individual humans, a considerable renovation of justice theories and thought seems required. We need to be able to devise approaches to answer some tough questions: (1) How far may we imagine new lifeforms and lifeworlds in the Anthropocene? (2) Are we free to imagine some continuities, or would the future be discontinuous, replete with new technologies, including the ethical/moral? (3) What obligations of justice are owed by co-nationals to all nationals? (4) If justice were to be conceived mainly in terms of procedural justice, how would the procedures be made relevant, since future generations cannot be at the table? (5) Will the basic interests and core rights that the future people have, or ought to have, be almost the same as now? (6) In what/which ways do we owe (and, if owed, how do we foster?) loyalty to the Planet as distinct from the World? (7) Is climate justice best brought about by being reverential to the anthropomorphic or by embracing all-species-relevant standards and norms of justice? ${ }^{99}(8)$ What are the geographies of climate injustice? Are they always geographies of rightlessness? ${ }^{100}$

To raise suchlike questions is not to deny (how can one possibly?) the reality of climate change, the looming and large scientific prognostications of climate catastrophes or to practise some form of climate change scepticism - or worse still - climate change nihilism. Rather, the questions pertain to the ways of devising a new theory of justice that informs human rights, governance and development in an Anthropocene era. Thinking about climate change justice requires 'epistemic insubordination' ${ }^{101}$ not semiotic enchantment - or worse still 'semiotic enslavement' ${ }^{102}$

(2002) 78(33) Economic Geography 257; R Parreñas, Servants of Globalization: Migration and Domestic Work (Stanford University Press, Stanford 2001); G Pratt, Working Feminism (Edinburgh University Press, Edinburgh 2004); D Wolf, Factory Daughters: Gender: Household Dynamics and Rural Industrialization in Java (University of California Press, Berkeley 1992); M Wright, 'Crossing the Factory Frontier: Gender, Place and Power in the Mexican Maquiladora' (1997) 29(3) Antipode 278-302; V Lawson, 'Hopeful Geographies: Imagining Ethical Alternatives: A Commentary on JK Gibson-Graham's "Surplus Possibilities: Postdevelopment and Community Economies"' (2005) 26(1) Singapore Journal of Tropical Geography 36-8; AR Hochschild, 'Global Care Chains and Emotional Surplus Value' in W Hutton and A Giddens, On the Edge: Living with Global Capitalism (Jonathan Cape, London 2000) 131-46; J Kelsey, Serving Whose Interests: The Political Economy of Trade in Services Agreements (Routledge Cavendish, Abingdon 2008); P Routledge, 'Engendering Gramsci: Gender, the Philosophy of Praxis, and Spaces of Encounter in the Climate Caravan, Bangladesh' (2015) 47(5) Antipode 1321-45; A Stewart, Gender Law and Justice in a Global Market (Cambridge University Press, Cambridge 2011).

99. These are not entirely random questions but still in quest of further refinement.

100. S Fisher, 'The Emerging Geographies of Climate Justice' (2015) 181 The Geographical Journal 73-82. For the notion of geographies of injustice and rightlessness, see U Baxi (n 42). 101. WD Mignolo, 'Introduction' (2007) 21(2-3) Cultural Studies 155-67.

102. F Guattari, 'Semiological Subjection, Semiotic Enslavement', in G Genosko (ed), The Guattari Reader (Blackwell, London 1966) 141-7. 